\title{
Applying the Triangulation Approach in IT - Business Strategic Alignment and Sustainable Competitive Advantage
}

\author{
Dmaithan Abdelkarim Almajali and Zulkhairi Md Dahalin \\ College of Arts \& Sciences, Universiti Utara Malaysia, Malaysia
}

\begin{abstract}
While researchers have encouraged more research on the causal chains between information technology investments and Business performance, the results of empirical studies have been inconclusive. This is partly due to the exclusion of IT-business strategic alignment. This study has examined the impact of IT-business strategic alignment antecedents in terms of leadership, structure and process, service quality, and value and belief on IT business strategic alignment in terms of alignment gap, followed by the impact of IT-business strategic alignment on sustainable competitive advantage. In order to explore the above research relationships, the study further utilizes the positivism paradigm by applying a mixed research method both quantitative and qualitative data. Such triangulation would help to provide more insight into the issues studied in this research. Particularly, this study has tested the research model by conducting 172 survey questionnaires with public shareholding firms in Jordan. After that, the study conducted several follow-up interviews in Jordan in order to further validate the research results. Thus, the results obtained from the structural equation modeling (SEM) technique and supplementary qualitative analysis of the interviews offer a valuable insight into the research. However, the universal applicability of this research may be limited due to the fact that the results are based only on the cross-sectional data from the Jordanian public shareholding firms. Consequently, further research is needed with regards to several countries since this would help to advance understanding of the IT-business strategic alignment issue and the conditions and outcomes of achieving it in different contexts.
\end{abstract}

Keywords: IT-Business strategic alignment, Alignment gap, Sustainable competitive advantage

\section{Introduction}

In order to improve their performance, firms invest heavily in IT such as hardware, software, network, and data components (Oana, 2010). However, based on the mixed findings of the linkage between IT spending and firm performance, some researchers in the MIS field suggest that IT-business alignment is a construct that can help organizations improve the positive impact of
IT on organizational success (e.g., Henderson \& Venkatraman, 1993; Luftman et al., 1993; Luftman \& Brier, 1999; Luftman, 2000; Kearns \& Lederer, 2001; Sabherwal \& Chan, 2001; Croteau \& Bergeron, 2001; Chan et al., 2006; Chan \& Reich, 2007; Dong et al., 2008; Masa'deh et al., 2008). For organizations to stay competitive in a dynamic business environment, they have to determine and understand how to manage IT strategically (Henderson \& Venkatraman, 1993).

Copyright (C) 2011 Dmaithan Abdelkarim Almajali, and Zulkhairi Md Dahalin. This is an open access article distributed under the Creative Commons Attribution License unported 3.0, which permits unrestricted use, distribution, and reproduction in any medium, provided that original work is properly cited. Contact author: Dmaithan Abdelkarim Almajali e-mail: admethan2004@yahoo.com 
Furthermore, the alignment between the business strategy and the strategic choices of IT deployment is a prominent area of concern that business and IT management struggle with (Johnson \& Lederer, 2010). Strategic alignment refers to "The degree to which the IT mission, objectives and plans support and are supported by the business mission, objectives and plans" (Reich \& Benbasat, 1996, 2000). However, regardless of a growing body of research, recent reviewers (Chan et al., 2006; Chan \& Reich, 2007; Masa'deh et al., 2008; Masa'deh \& Kuk, 2009) have continuously called for more research into the factors that affect ITbusiness alignment. In response, to fill this research gap, this study tries to make an original contribution to the existing body of knowledge in the area of MIS by exploring the association between IT-business strategic alignment and sustainable competitive advantage. The contribution of the current study to IT-business strategic alignment literature will be the new theoretical approach of investigating strategic alignment, which has not been explored in the field of IS. This is achieved by exploring the relationships between several factors (i.e. leadership, structure and process, service quality, and value and belief) on IT-business strategic alignment to achieve sustainable competitive advantage and how strategic alignment can mediate the relationship between these factors and sustainable competitive advantage. After the introduction, this paper continues to discuss new conceptualization of alignment in the next section, followed by the discussion of hypotheses formulation and methodology. The last section covers the detail discussion of the results and conclusion.

\section{Alignment Gap}

Despite the criticality of business and IT relationship, few attempts have been taken to investigate that relationship further. Compared to the issue of managing relationships, the literature is rich on the issue of control of resources with regard to business-IT strategic alignment (Ward \&
Peppard, 1996; Chan \& Reich, 2007; Masa'deh et al, 2008; Masa'deh \& Kuk, 2009). Although the alignment gap represents an important concept in business-IT strategic alignment, it has not been presented or discussed explicitly in the context of business-IT strategy. Moreover, to the best of the researcher's knowledge, no particular evidence refers to the concept of alignment gap between business strategy and IT strategy. Therefore, the focus in this paper is to explore alignment gap and to focus attention on the question of aiming to determine the reasons why the alignment gap exists between business strategy and IT strategy. This will help business and IT managers to deal with unmanageable issues as a result of the alignment gap, and different management practices for bridging the alignment gap between business strategy and IT strategy. Several scholars and authors mentioned and discussed the term 'gap' or 'culture gap' in different articles (Ward \& Peppard, 1999; Grindley, 1992; Luftman, 2003). However, none of these scholars or authors attempted to provide a critical review of the concept alignment gap between business strategy and IT strategy in a conceptual manner (Almajali \& Dahalin, 2010b). Some scholars (e.g., Chan \& Reich, 2007) called for further adjustments to the concept of alignment by applying new theoretical approaches which have not been explored in the field of IT. Thus, this study aims to conceptualize IT-business strategic alignment into the alignment gap.

The concept of alignment gap between business strategy and IT strategy has emerged due to the fact that there are two separate organizational units in any organization. One is the IT department, which is responsible for IT activities, and the other one is the business department that has led to the appearance of the gap between IT functions and business activities. IT function generally refers to the IT services provided by the individuals to the organization. These individuals are usually highly skilled IT professionals, who have certain amount of knowledge and experience 
in software engineering and technical aspects of computer hardware and software systems, and who carry out a variety of tasks to deal with the requirements of the firm for IT services. Some functions of IT professionals may include designing, implementation, and maintenance of the software programs, including data processing (Ward \& Peppard, 2002; Sage, 2002).

The concept of gap used here, based on literature, refers to what is called 'culture gap', which is a variable that explains the challenges that can exist between the IT function and other business functions in an organization.

The culture gap concept consists of four dimensions: i.e., leadership, structure and process, service quality, and values and belief (Ward \& Peppard, 1999, 2002). The culture gap has been identified as a key factor in limiting the successful utilization of IT in the organization (Grindly, 1992). Leadership is elaborated upon by reflecting both the leadership of the CIO and the leadership of the CEO. Baker et al. (2004) argue that a successful alignment between business strategy and IT needs a well-built leadership structure. Structure and process are concerned with the way in which an organization manages its IT, such as the involvement of business management in IT strategy development, aligning IT strategy with business objectives, and delivering IT benefits (Earl, 1993). Service quality is considered to be vital in determining the customer supplier relationship.

Such relationships could be strengthened by the IT department by focusing on the development of IT outsourcing and the level of service that clients expect from the vendor (Pitt et al., 1995). The last dimension, values and belief, shape how attitudes, behaviors, and practices develop (Smircich, 1983). Hence, the values and belief of a firm member have great effect on several dimensions of IT, including the way it is managed.
Culture is an abstract concept referring to the culture in the organizational context. It is a shared set of values, behaviors, and beliefs together with attitudes and experiences that represent unique characters taking the form of rules of behavior in a work group or organization (Galliers et al., 1994). Reasons that cause the misalignment between business and IT include lack of common understanding of the concept of strategic alignment, and depending on classical assumptions for strategic planning process or ad-hoc IT investments in organization (Oana, 2010). Oana further indicated that the misalignment leads to missing competitive advantages and opportunities, increasing wasted time, increasing costs and creating negative environment for IT investments. Indeed, probably the most common business concept today is competitive advantage. Despite of its wide use, few researchers have attempted to define the concept, and it is often confused with distinctive competence (Day, 1994). Exceptions include work by Ansoff et al. (1987), who broadly defined competitive advantage as the "properties of individual product/markets which will give the firm a strong competitive position". Porter's (1985) book titled 'Competitive Advantage' propelled the concept of competitive advantage into popular business vernacular. Porter did not articulate the definition of the concept but explained that a competitive advantage refers to organizational factors that enable a firm to outperform its competitors. As such, Porter argued that sustaining competitive advantage should be the central purpose of an organization's competitive strategy that creates sustainable value.

\section{Research Hypotheses}

We formulate our research hypotheses based on the above discussion and the extant literature of strategic alignment. The model of this study comprises main effects of four antecedents (i.e., leadership, structure and process, service quality, value and belief) on strategic alignment and its effect on sustainable competitive advantage. 
1. Firms that pursue strategic alignment will enhance their sustainable competitive advantage.

2. The stronger leadership between business and IT managers, the greater level of strategic alignment.

3. The stronger structure and process with the business plan and IT plan, the greater the manager's engagement in strategic alignment.

4. The higher level of service quality between the business and IT managers, the greater the manager's engagement in strategic alignment.

5. The stronger values and belief in the business plan and IT plan, the greater the manager's engagement in strategic alignment

6. The Strategic alignment will mediate the relationship between leadership and sustainable competitive advantage.

7. The Strategic alignment will mediate the relationship between structure and process and sustainable competitive advantage.

8. The Strategic alignment will mediate the relationship between service quality and sustainable competitive advantage.

9. The Strategic alignment will mediate the relationship between values and beliefs and sustainable competitive advantage.

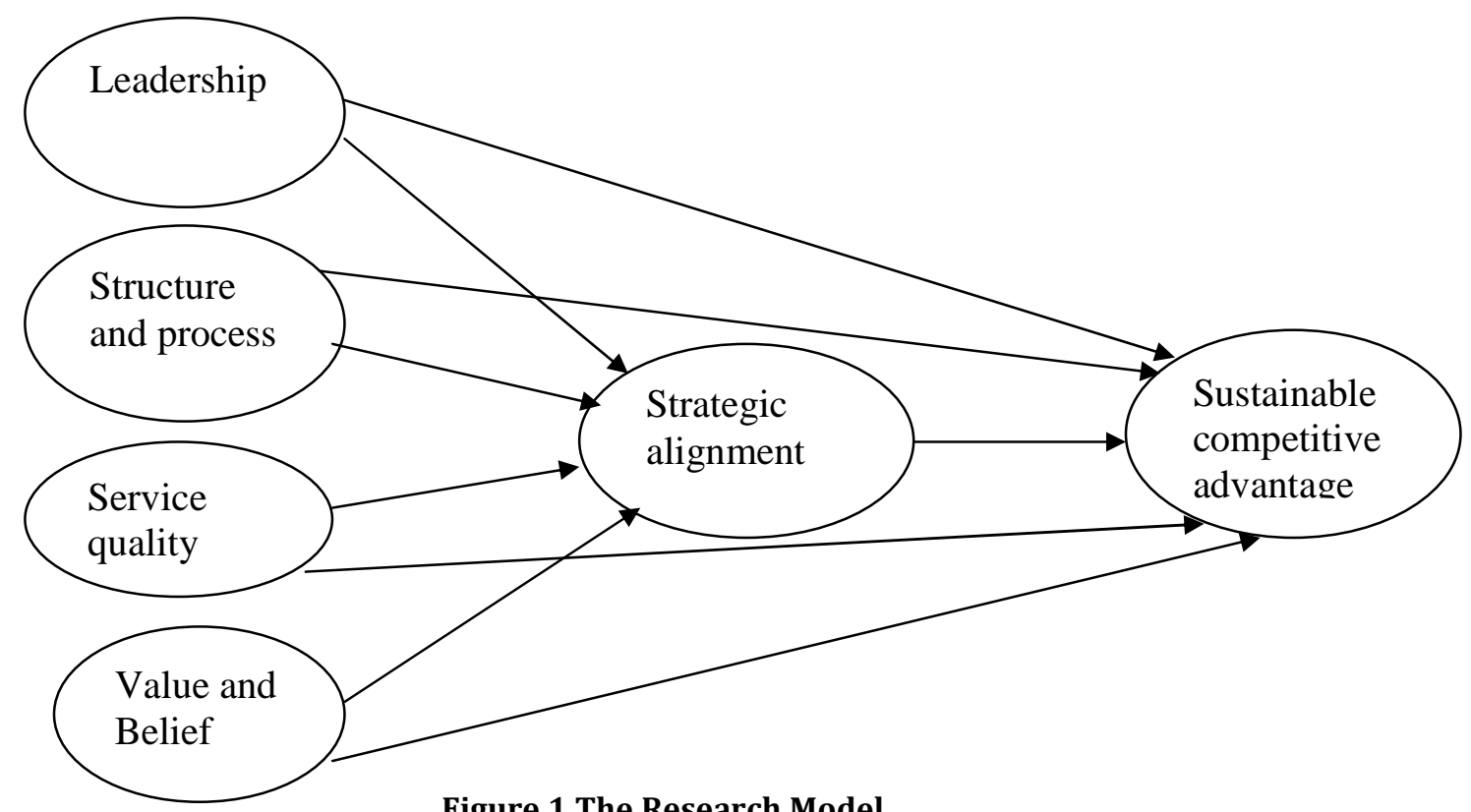

Figure 1.The Research Model

\section{Research Method}

\section{Pilot Test and Data Collection}

Since both of the single approaches (i.e., qualitative and quantitative) have strengths and weaknesses, the combination between such approaches (e.g., employing both interviews and survey questionnaires for data collection) could be used to strengthen the validity of research (Nau, 1995). Triangulation, as defined by Jick (1979), is a vehicle for cross validation, when two or more different methods are found to be matching, and yield new ideas and analogous data. Also, (Das 1983; Yin, 1994; Patton, 2002) defined triangulation as a combination 
of methodologies in studying a similar phenomenon.

Three Jordanian IT managers and two MIS academic professors participated in a pilot test. They completed the survey in the presence of the first author. Then, they commented on the content, length, and overall appearance of the questionnaire. Changes and modifications were made to the survey. Further, in order to ensure adequacy of response, a cover letter was accompanied each questionnaire to emphasize the importance of the respondents' participation. Moreover, the researchers have chosen the country of Jordan to carry out the data collection since scholars like Chan et al., (2006) called for such research in different cultures; and as this may open the gate to further research opportunities. Data for this research was obtained from IT managers of Jordanian public shareholding firms. The research population consists of all Jordanian banking, insurance, services, and manufacture companies having a registered website, and engaging in both business and IT activities.

In the absence of any official lists, various government databases were reviewed; according to the Amman Stock Exchange, and the Jordanian Securities Depository Center, the total number of companies stood at 200. A total of 172 managers returned the survey with a high response rate of $86 \%$. The respondents were IT managers in the firms who have responsibility for IT functions of their firms. The qualitative research consisted of face-to-face in-depth interviews with IT managers. Table 1 in appendix, shows the questions which have been raised for the respondents. The interviews were conducted in a semi-structured format that allowed respondents to express their own view points (Flick, 2002). All in-depth interviews were conducted in Arabic language. Extensive notes were taken during the interview. Here, we highlight the key issues mentioned in each interview and also combine the most common issues mentioned by the interviewee. To identify the major issues to the factors which affect the relationship between IT strategy and business strategy, passages and rewording of the same or similar interpretations were summarized and categorized according to the four dimensions discussed above. Table 2 in Appendix presents the profile of the informants interviewed.

\section{Measures}

We developed a field survey for IT managers. All the research constructs were measured using closed-end, seven-point Likert-scale items, with scales ranging from 1 = "strongly disagree", 2 = "disagree", 3 = "somewhat disagree", 4 = "neither agree nor disagree", 5 = "somewhat agree", $6=$ "agree", to $7=$ "strongly agree". Business and IT managers leadership variable was measured using six items drawn from Ward and Griffiths (1999). Structure and process mechanism was measured using six items adapted from Ward and Peppard (1996). Service quality variable was measured using five items drawn from Pitt et al. (1995). Values and beliefs were measured using six items drawn from Grindley (1992). Strategic alignment was measured using six items drawn from Pierce (2002). Sustainable competitive advantage was measured using six items drawn from $\mathrm{Al}$ majali and Dahalin (2010a) and DeVilliers (2006).

\section{Data Analysis and Results}

In order to examine whether the antecedents discussed above could impact IT-business strategic alignment and sustainable competitive advantage in Jordanian public shareholding firms, a number of statistical tests were carried out. The statistical tests were carried out using Structural Equation Modeling (SEM) techniques using the AMOS (Analysis of Moment Structures) software package version 6 . Table 3 in the appendices displays different types of goodness of fit indices in assessing our initial specified model. It shows that the research constructs fits the data moderately according to the absolute, incremental, and parsimonious model fit measures, comprising chi-square per degree of freedom ratio $\left(x^{2} / \mathrm{df}\right)$, Incremental Fit Index (IFI), Tucker-Lewis Index (TLI), Comparative Fit Index (CFI), and 
Root Mean Square Error of Approximation (RMSEA). Furthermore, we examined the standardized regression weights for the research's indicators and found that some indicators had a low loading towards the latent variables. In particular, the indicators are, SP1 $=0.484$, SQ3 $=0.391$, and SQ5 = 0.476 . Moreover, since all of these items did not meet the minimum recommended value of factor loadings of 0.50 (Newkirk \& Lederer, 2006), and because the initial fit indices were moderately fit to the sample data, they were all removed and excluded from further analysis. Consequently, the measurement model was modified and showed a better fit to the data (as shown in Table 1 in the appendices), although $x^{2} / \mathrm{df}$ and RMSEA did not change for the final model, the IFI $=0.81$, TLI $=0.80$, and CFI $=$ 0.81 indicated better fit to the data after deleting the low factor loading items.

\section{Discussion and Implications}

This paper contributes to the strategic alignment literature by developing and empirically testing a causal chain model of alignment with the specification of four antecedents. Table 4, in the Appendix indicates the path coefficient and t-value of each proposed path. This study revealed that strategic alignment has significant influence on sustainable competitive advantage. The study found that strategic alignment has significant relationship with sustainable competitive advantage in both the survey, as shown in hypothesis $\mathrm{H} 1$ in table 4 , and in the interview studies. This is to say the firms that are pursuing strategic alignment have greater ability to enhance their sustainable competitive advantage. Indeed, in relation to this study, some IT managers stressed that strategic alignment enhance sustainable competitive advantage in Jordanian organization. Overall, this study provides support from both surveys and interviews that firms pursuing strategic alignment can achieve the greater enhancement of their sustainable competitive advantage.

The element of business-IT interaction is an important focus in the fields of MIS and management. The principal finding of the survey study, as shown in hypotheses H2, and the interviews, was that the existence of leadership between business and IT managers in Jordan to have a positive relationship with strategic alignment. Hence, the more IT managers' involvement in interaction with top management, the better is their experienced level of strategic alignment. The positive relationship between business-IT interaction and strategic alignment is consistent with the findings of Lind and Zmud (1991). Overall, this study provides support from both surveys and interviews that the greater the IT managers' involvement in interaction with top management, the greater is the likelihood that they will experience higher levels of strategic alignment.

It is found that the connection between IT plan and business plan to have no strong relationship with strategic alignment in both the survey as shown in hypotheses $\mathrm{H} 3$ and interview studies. Therefore, this study has failed to support the association between IT plan and business plan and strategic alignment. This is in line with Kearns and Lederer (2000), who frankly declared that if IT does not collaborate reciprocally with other functional areas, then alignments will not occur.

It is found that service quality has significant relationship with strategic alignment in the survey as shown in hypotheses H4. However, this study successfully supported the relationship between service quality and strategic alignment in the survey. This implies that, if IT collaborates reciprocally with other functional areas, it will facilitate the alignments. However, during the interview in relation to this study, some IT managers stressed that service quality does not support strategic alignment. This study found some concerns related with service quality such as inadequate training programs, which hinder the finding of solutions to enhance product or service. Besides this, other concerns include the issues affecting the overall delivery of products or services. Some IT managers stressed the same opinion. 
The element of value and belief is an important focus in the fields of MIS and management. The principal finding of the survey study, as shown in hypotheses H5, and in the interviews was that the existence of value and belief between business and IT managers in Jordan has a positive significant effect on strategic alignment. Hence, the stronger the value and belief between IT managers and the top management, the greater the alignment is.Overall, this study provides support from both surveys and interviews that the stronger value and belief between IT managers with top management will lead to greater engagement of the manager's in strategic alignment.

Furthermore, as the results shown in Table 5 in appendix, there are two factors, namely, leadership and structure and process, for which strategic alignment did not play mediating effect on sustainable competitive advantage. Thus, H6, and H7 were not supported. Besides, there are two factors, namely, service quality and value and belief, for which strategic alignment played mediating effect on sustainable competitive advantage. Thus, H8, and H9 were supported. This study has supported this result from both interview and survey. Table 6 in appendix shows the main issue of the interviews.

\section{Conclusions, Limitations, and Future Research Directions}

The proposed causal model tested in this study contributes to the enrichment of the research in the field of strategic alignment of IT by considering an integrative approach containing the antecedents of IT-business alignment, the mediator strategic alignment, and the outcome as sustainable competitive advantage. Moreover, this research makes a methodological contribution to IS theory by using structural equation modeling with the powerful AMOS approach that assists data analysis. By using the rigorous SEM tests in this thesis, a precise foundation has been established for the theory building in the area of strategic alignment. In summary, it is expected that this study will provide a better understanding of how managers experience into strategic alignment, and in turn how it affects sustainable competitive advantage.

There are some limitations of the study. The first limitation is that the proposed conceptual model is based on the crosssectional data from the Jordanian public shareholding firms. Therefore, longitudinal investigations are preferred for better implications of the strategic alignment. In addition, although the response rate of this study was sufficient for the condition of statistical analysis, the percentage of those who did not respond was still observable. In other words, even though the research results could be representative, it is reasonable to be watchful about its generalization. Thus, to increase statistical validity, further research should consider higher response rates. Also, the data and results reported in this paper were based on a single country, Jordan, and in turn are applicable specifically to the Jordanian context. Thus, this raises inquiries regarding the generalisability to other cultures and different contexts. Consequently, further research is needed with regards to several countries since this would help to advance understanding of the IT-business strategic alignment issue and the conditions and outcomes of achieving it from different nationwide origins in different contexts. All in all, although this paper investigated several propositions and offered empirical support for the acceptance and refusal of some of these propositions, more generalizations on the application of the theoretical premises that developed in building the research model will be needed to enrich to build the alignment theory. This is to say, a more generalized research model that compensate the current research limitations by adding further impacting variables to the model and obtain a more representative sample from different sectors will be required. Finally the data collection method was costly as a survey in Jordan is expensive. Finally, the cost of questionnaire distribution in Jordan was also very high. 


\section{Acknowledgment}

I would like to express my sincere gratitude to my supervisor Prof. Dr. Zulkhairi Md Dahalin for his guidance, encouragement , patience, and support throughout this work.

\section{References}

Al majali, D. \& Dahalin, Z. (2010). 'ITbusiness Strategic Alignment and Sustainable Competitive Advantage,' Proceedings of the Conference of Organizational Innovation, July, Malaysia.

Al majali, D. \& Dahalin, Z. (2010b). 'Diagnosing the Gap in IT - Business Strategic Alignment: A Qualitative Analysis Among Public Shareholding Firms in Jordan,' International Journal of Electronic Business Management , 8 (4),255- 262.

Ansoff, H. I. (1987). "Strategic Management of Technology," Journal of Business Strategy, 7(3), 28-39.

Baker, J., Parasuraman, A., Grewal, D. \& Voss, G. B. (2002). "The Influence of Multiple Store Environment Cues on Perceived Merchandise Value and Patronage Intentions," Journal of Marketing, 66(2), 120-141.

Chan, Y. E. \& Reich, B. H. (2007). "IT Alignment: What Have we Learned?," Journal of Information Technology, 22(4), 297-315.

Chan, Y. E., Sabherwal, R. \& Thatcher, J. B. (2006). "Antecedents and Outcomes of Strategic IS Alignment: An Empirical Investigation," IEEE Transactions on Engineering Management, 53(1), 27- 47

Croteau, A. \& Bergeron, F. (2001). "An Information Technology Trilogy: Business Strategy, Technological Deployment and Organizational Performance," The Journal of Strategic Information Systems, 10(2), 77-99.

Das, T. (1983). 'Qualitative Research in Organisational Behavior,' Journal of Management Studies, 20 (3), 308-318.
Day, G. (1994). 'Strategic Market Planning: The Pursuit of Competitive Advantage,' West Publishing, St Paul, MN.

De Villiers, R . (2006). 'Sources of Sustainable Competitive Advantage for Business Operating in Global MarketPplace,' Unpublished doctoral Dissertation, University of Pretoria: The USA

Dong, X., Liu, Q. \& Yin, D. (2008). "Business Performance, Business Strategy, and Information System Strategic Alignment: an Empirical Study on Chinese Firms," Tsinghua Science and Technology, 13 (3), 348-354.

Earl, M. J. (1993). "Experiences in Strategic Information Systems Planning," MIS Quarterly, 17(1), 1-24.

Flick, U. (2002). 'An Introduction to Qualitative Research,' Sage, London

Galliers, R. D., Meriali, Y. \& Spearing, L. (1994). "Coping with Information Technology? How British Executives Perceive the Key Information Systems Management Issues in the Mid-1990s," Journal of Information Technology, 9, 233238.

Grindley, K. (1992). "Information Systems Issues Facing Senior Executives: The Culture Gap," The Journal of Strategic Information Systems, 1(2), 57-62.

Henderson, J. C. \& Venkatraman, N. (1993). "Strategic Alignment: Leveraging Information Technology for Transforming Organizations," IBM systems Journal , 32(1), 4-16.

Jick, T. D. (1979). "Mixing Qualitative and Quantitative Methods: Triangulation in Action," Administrative Science Quarterly , 24(4), 602-611.

Johnson, A. M. \& Lederer, A. L. (2010). "CEO/CIO Mutual Understanding, Strategic Alignment, and the Contribution of IS to the Organization," Information \& Management , 47(3), 138-149. 
Kearns, G. S. \& Lederer, A. L. (2000). "The Effect of Strategic Alignment on the Use of ISbased Resources for Competitive Advantage," The Journal of Strategic Information Systems , 9(4), 265-293.

Kearns, G. S. \& Lederer, A. L. (2001). "Strategic IT-Alignment: A model for competitive advantage," Proceedings of the 2nd ICIS, 1-12, Barcelona.

Lind, M. R. \& Zmud, R. W. (1991). "The Influence of a Convergence in Understanding between Technology Providers and Users on Information Technology Innovativeness," Organization Science, 2(2), 195-217.

Luftman, J. (2000). 'Assessing Business-IT Alignment Maturity,' Communication of AIS, $4(14)$.

Luftman, J. (2003). Measure your Business-IT Alignment, Optimize: Business Execution for CIOs Magazine, 26.

Luftman, J. \& Brier, T. (1999). "Achieving and Sustaining Business-IT Alignment," California Management Review , 42(1), 109-122.

Luftman, J. N., Lewis, P. R. \& Oldach, S. H. (1993). "Transforming the Enterprise: The Alignment of Business and Information Technology Strategies," IBM Systems Journal , 32, 198-221.

Masa'deh, R., and Kuk, G. (2009, August 711). 'Antecedents and Intermediaries between Strategic Alignment and Firm Performance,' Proceedings of the 2009 Conference of the Academy of Management Annual Meeting(AOM), Illinois, Chicago, U.S.A.

Masa'deh, R., Hunaiti, Z., and Bani Yaseen, A. (2008). 'An Integrative Model Linking ITBusiness Strategic Alignment and Firm Performance: The Mediating Role of Pursuing Innovation and Knowledge Management Strategies,' In the Communications of the International Business Information Management Association (IBIMA) Journal, 2 (24), 180-187.
Nau, D. S. (1995) "Mixing Methodologies: Can Bimodal Research be a Viable Post-positivist Tool," The Qualitative Report, 2(3), 1-5.

Newkirk, H. E. \& Lederer, A. L. (2006). "The Effectiveness of Strategic Information Systems Planning under Environmental Uncertainty," Information \& Management, 43, 481-501.

Patton, M. Q. (2002). Qualitative Research and Evaluation Methods, Sage Publications Inc.

Pierce, A. C. (2002). 'The Effect of Business and Information Technology Strategic Alignment on Information Technology Investment Returns and Corporate Performance,' Unpublished Doctoral Dissertation, Nova Southeastern University. Retrieved May 15, 2010, from the UMI ProQuest Digital Dissertations database.

Pitt, L. F., Watson, R. T. \& Kavan, C. B. (1995). "Service Quality: A Measure of Information Systems Effectiveness," MIS Quarterly, 19(2), 173-187.

Porter, M. E. (1985). 'Competitive Advantage: Creating and Sustaining Superior Performance,' New York: Free Press.

Reich, B. (2000). "Factors that Influence the Social Dimensions of Alignment between Business and Information Technology Objectives," MIS Quarterly, 24(1), 81-113.

Reich, B. H. \& Benbasat, I. (1996). "Measuring the Linkage between Business and Information Technology Objectives," MIS Quarterly, 20(1), 55-81.

Sabherwal, R. \& Chan, Y. E. (2001). "Alignment between Business and IS Strategies: A Study of Prospectors,Analyzers, and Defenders," Information Systems Research, 12(1), 11-33.

Sage, A. P. (2002). "Information Technology," In AccessScience@McGraw-Hill, http://www.accessscience.com, DOI 
10.1036/1097-8542.757582; last modified: March1,2002 - Last accessed 2009-03-14.

Smircich, L. (1983). "Concepts of Culture and Organizational Analysis," Administrative Science Quarterly, 28(3), 339-358.

Velcu, O. (2010). "Strategic Alignment of ERP Implementation Stages: An Empirical Investigation," Information \& Management, 47(3), 158-166.

Ward, J. \& Griffiths, P. (1999) 'Strategic Planning For Information Systems,' Wiley, New York.

Ward, J. \& Peppard, J. (1996). "Reconciling the IT/Business Relationship: a Troubled Marriage in Need of Guidance," Journal of Strategic Information Systems , 5, 1, 37-65.
Ward, J. \& Peppard, J. (1999). " 'Mind the gap': Diagnosing the Relationship between the IT Organization and the Rest of the Business," Journal of Strategic Information Systems , 8(1), 29-60.

Ward, J. \& Peppard, J. (2002). "Strategic Planning for Information Systems (3rd ed.)," John Willey \& Sons.

Yin, R. K. (1994). 'Case Study Research: Design and Methods,' Thousand Oaks: Sage Publications. 


\section{Appendix:}

Table (1): The Questions That Have Been Raised in the Interviews are as Follows:

\begin{tabular}{|l|l|}
\hline $\begin{array}{l}\text { Number } \\
\text { of } \\
\text { question }\end{array}$ & Question \\
\hline 1 & $\begin{array}{l}\text { How about leadership in your organization? Do business and IT managers interact } \\
\text { and communicate? And how frequently does that happen? }\end{array}$ \\
\hline 2 & $\begin{array}{l}\text { Could you tell me about structure and process? Is there any } \\
\text { interaction/connection between business and IT departments? }\end{array}$ \\
\hline 3 & $\begin{array}{l}\text { Could you tell me about service quality and (value and belief) toward strategic } \\
\text { alignment in the organization? }\end{array}$ \\
\hline 4 & $\begin{array}{l}\text { How do you think the relationship between achieving strategic IS alignment and } \\
\text { firm's sustainable competitive advantage? }\end{array}$ \\
\hline
\end{tabular}

Table (2): Informants' Profile

\begin{tabular}{|l|l|l|l|l|l|}
\hline Number & Gender & Age & Position & Experience & Sector \\
\hline 1 & Male & 35 & IT manager & 5 & Banking \\
\hline 2 & Male & 40 & IT manager & 7 & Service \\
\hline 3 & Male & 55 & IT manager & 10 & Manufacturing \\
\hline 4 & Male & 51 & IT manager & 9 & Insurance \\
\hline
\end{tabular}

Table (3): Measurement Model Fit Indices

\begin{tabular}{|c|c|c|c|c|c|c|c|c|}
\hline Model & $\mathbf{x}^{\mathbf{2}}$ & $\mathbf{d f}$ & $\mathbf{P}$ & $\mathbf{x}^{\mathbf{2}} / \mathbf{d f}$ & $\mathbf{I F I}$ & $\mathbf{T L I}$ & $\mathbf{C F I}$ & RMSEA \\
\hline Initial Estimation & 2548.191 & 874 & 0.00 & 2.91 & 0.71 & 0.68 & 0.71 & 0.106 \\
\hline Final Model & 884.181 & 335 & 0.00 & 2.63 & 0.81 & 0.80 & 0.81 & 0.08 \\
\hline
\end{tabular}


Table (4): Summary of Proposed Results for the Theoretical Model

\begin{tabular}{|l|c|c|c|c|}
\hline $\begin{array}{c}\text { Research proposed } \\
\text { paths }\end{array}$ & t- value (CR) & $\begin{array}{c}\text { Coefficient } \\
\text { value } \\
\text { (Std.estim) }\end{array}$ & P - value & $\begin{array}{c}\text { Empirical } \\
\text { Evidence }\end{array}$ \\
\hline SA sp & .144 & .011 & .885 & Not supported \\
\hline SA VB & 2.420 & .100 & .036 & Supported \\
\hline SA & 2.705 & .206 & .007 & Supported \\
\hline SA SA & 2.312 & .114 & .041 & Supported \\
\hline SUS & 4.779 & .316 & $* * *$ & Supported \\
\hline
\end{tabular}

$* * * \mathrm{P} \leq .005, * * \mathrm{P} \leq .01, * \mathrm{P} \leq .05$

Note. LS: Leadership; SP: Structure and Process; SQ: Service Quality; VB: Values and Beliefs; SA: Strategic Alignment; SUS: Sustainable Competitive Advantage.

Table (5): Mediating Effect of Strategic Alignment

\begin{tabular}{llcccccc}
\hline Hypothesis & From & Mediation & To & $\begin{array}{l}\text { Direct } \\
\text { effect }\end{array}$ & $\begin{array}{l}\text { Indirect } \\
\text { effect }\end{array}$ & $\begin{array}{l}\text { Total } \\
\text { Effect }\end{array}$ & Mediating \\
\hline \hline H6 & LS & SA & SUS & .175 & .036 & .211 & Not \\
H7 & SP & SA & SUS & .068 & .004 & .072 & Mediating \\
H8 & SQ & SA & SUS & .005 & .031 & .036 & Mediating \\
H9 & VB & SA & SUS & .056 & .065 & .121 & Mediating
\end{tabular}


Table (6): Summary of Issues in Interviews

\begin{tabular}{|c|c|c|c|c|}
\hline Issues & IT1 banking & IT2 service & $\begin{array}{l}\text { IT3 } \\
\text { manufacturing }\end{array}$ & IT4insurance \\
\hline Leadership & $\begin{array}{l}\text { Higher level of } \\
\text { communication } \\
\text { through face to } \\
\text { face, electronic } \\
\text { mail and memos }\end{array}$ & $\begin{array}{l}\text { Higher level of } \\
\text { communication } \\
\text { through regular } \\
\text { meeting }\end{array}$ & $\begin{array}{l}\text { Less level of } \\
\text { communication at } \\
\text { the end of the } \\
\text { year }\end{array}$ & $\begin{array}{l}\text { There is no } \\
\text { communication } \\
\text { between IT } \\
\text { department and } \\
\text { top management }\end{array}$ \\
\hline $\begin{array}{l}\text { Structure } \\
\text { and process }\end{array}$ & $\begin{array}{l}\text { Higher level of } \\
\text { cooperation } \\
\text { between IT } \\
\text { department and } \\
\text { top management }\end{array}$ & $\begin{array}{l}\text { Higher level of } \\
\text { cooperation with } \\
\text { high level of long } \\
\text { term planning }\end{array}$ & $\begin{array}{l}\text { Lower level of } \\
\text { connection } \\
\text { between IT plan } \\
\text { and business plan }\end{array}$ & $\begin{array}{l}\text { There is a gap } \\
\text { between IT plan } \\
\text { and business plan }\end{array}$ \\
\hline $\begin{array}{l}\text { Service } \\
\text { quality }\end{array}$ & $\begin{array}{l}\text { Greater level of } \\
\text { concern to } \\
\text { improve service }\end{array}$ & $\begin{array}{l}\text { Greater level of } \\
\text { concern to find } \\
\text { best solution to } \\
\text { enhance service }\end{array}$ & $\begin{array}{l}\text { Greater level of } \\
\text { concern to } \\
\text { enhance service }\end{array}$ & $\begin{array}{l}\text { Lower level of } \\
\text { concern to } \\
\text { enhance service }\end{array}$ \\
\hline $\begin{array}{l}\text { Value and } \\
\text { belief }\end{array}$ & $\begin{array}{l}\text { Have less } \\
\text { technical } \\
\text { knowledge }\end{array}$ & $\begin{array}{l}\text { Have less } \\
\text { technical } \\
\text { knowledge }\end{array}$ & $\begin{array}{l}\text { Higher Negative } \\
\text { attitude toward s } \\
\text { IT }\end{array}$ & $\begin{array}{l}\text { Higher Negative } \\
\text { attitude toward s } \\
\text { IT }\end{array}$ \\
\hline $\begin{array}{l}\text { Strategic } \\
\text { alignment } \\
\text { and } \\
\text { sustainable } \\
\text { competitive } \\
\text { advantage }\end{array}$ & $\begin{array}{l}\text { A Great level of } \\
\text { concern between } \\
\text { IT department } \\
\text { and top } \\
\text { management, also } \\
\text { higher profit }\end{array}$ & $\begin{array}{l}\text { A Great level of } \\
\text { concern between } \\
\text { IT department } \\
\text { and top } \\
\text { management, but } \\
\text { less profit }\end{array}$ & $\begin{array}{l}\text { Lower level of } \\
\text { concern between } \\
\text { IT department } \\
\text { and top } \\
\text { management, } \\
\text { Also less profit }\end{array}$ & $\begin{array}{l}\text { There is a Great } \\
\text { level of concern } \\
\text { between IT } \\
\text { department and } \\
\text { top management, } \\
\text { also higher profit. }\end{array}$ \\
\hline
\end{tabular}

